\title{
IMPLEMENTATION OF A NEW METHODOLOGY OF EMISSION INSPECTIONS IN MOTOR VEHICLES WITH AN ADVANCED EMISSION SYSTEM
}

\author{
Peter LENĎÁK,' L'ubomír HUJO, ${ }^{2}$ Juraj JABLONICKÝ, ${ }^{2}$ Michal ANGELOVIČ² \\ S-EKA, spol. s r. o., Nitra, Slovakia' \\ Slovak University of Agriculture in Nitra, Slovakia²
}

\begin{abstract}
This paper focuses on the implementation of a new exhaust-emission measurement system of motor vehicles equipped with a petrol engine and an advanced emission system. Our study deals with new methods of emission inspections using on-board diagnostics in order to increase the efficiency of emission inspection itself. The aim of implementing the new method of emission measurement is to eliminate vehicles that contribute to air pollution with emissions, due to an insufficient technical condition of the petrol engine fuel supply system.
\end{abstract}

Keywords: emission inspection, on-board diagnostics, emission measurement methodology, environment

An increasing trend of technology development around the world results in undesirable side effects resulting in environmental pollution. A massive expansion of transport contributes significantly to sharpening the ecological situation. The transport sector is one of the main factors having an effect not only on environmental pollution (the largest part of harmful emissions) but also on the existence of global energy issues. The transport sector is the second largest global producer of $\mathrm{CO}^{2}$, contributing by $14 \%$ to atmospheric pollution. Within transport, motor vehicles contribute to $\mathrm{CO}^{2}$ production by almost $45 \%$. Besides that, the transport sector is one of the largest consumers of fossil fuel energy sources, resulting in a significant negative effect on environmental pollution. Increasingly strict legislative limits for the production of pollutants force vehicle manufacturers to reduce the produced volume of harmful emissions and thereby to increase the ecological safety of new vehicles. Newly manufactured motor vehicles have a high level of ecological safety, which is verified by approval tests. The combustion of hydrocarbon fuel results in the production of combustion products, which have negative effects on the environment and on a human body as well. Therefore, it is important to reduce harmful emissions produced by the combustion engine. There are two main concepts in reducing the transport impact on the environment in the area of environmental pollution elimination caused by the leakage of pollutants during the operation of combustion engines.

At the present time, as regards environmental protection, it is important to focus on motor vehicles in traffic. In technically and economically developed countries, the system of periodical inspections has been developed and advanced since the 1980s, focusing on emissions of motor vehicles for all emission systems and all types of driving mechanisms. The aim of this paper is to achieve the motor vehicles in traffic do not pollute the environment above the level determined by their technical capabilities given in manufacturing with respect to their technical life, or above allowable limit values determined by a public authority.

The issue of emissions in relation to the environment is increasing its topicality, which is caused by its alarming situation. Subsequently, there is a growing strictness of implemented European emission standards. In transport, motor vehicles belong to the main pollutive elements, especially in a city and intercity cycle with a higher concentration of population (Šimor, 2008).

The concept of emission inspection of motor vehicles and its adaptation to an on-going development in the area of combustion engines and their fuels as well as an increasing informative capability of such an inspection of the vehicle's technical condition is a subject of our study (Lendák, 2008; Bibza, 2007).

\section{Material and methods}

Lendák (2012) notes that the emission inspection of petrol engines with an advanced emission system is being performed in Slovak conditions nowadays. Because of advances in technology and a constant increasing of the technical level of motor vehicles, it is important to assess the existing technical solution and the method and scope of monitoring the emissions of engines. The aim of this study is to describe the concept of an innovative method that will consider the development of technical solutions for motor vehicles, will be in accordance with applicable legislation, and will be applicable to a wide spectrum of motor vehicles with an advanced emission system.

\section{Analysis of the existing methodical procedure for vehicle emission inspection}

In accordance with the defined objective, it was necessary to analyse the strengths and weaknesses of the existing methodical procedure for performing the emission inspection of motor vehicles in question in terms of adaptation to increasing their technical level. The analysis of the existing methodical procedure will be solved in terms of:

- the scope of actions in the emission inspection of a motor vehicle;

- the method of inspection of engine emission condition;

- technological equipment of an emission inspection station; 

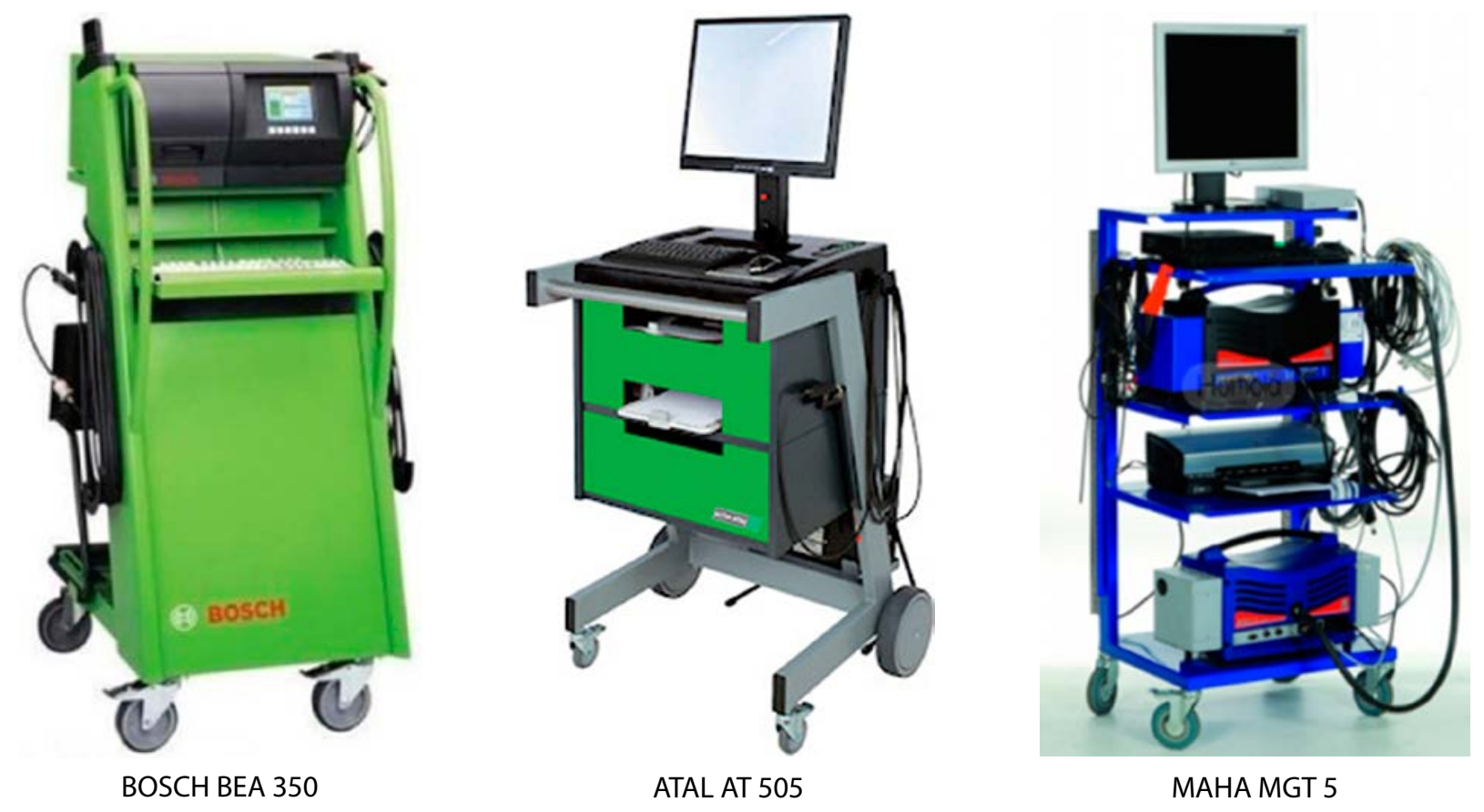

Figure 1 Measuring devices used in experimental measurements

- knowledge requirements and practical skills of emission inspection technicians.

\section{Concept of an innovative method for the inspection of engine emission condition}

Based on the analysis of existing methodical procedure and on understanding the issue in question, it was important to innovate the inspection method of engine emission condition to ensure:

- the increasing of an informative capability of vehicle emission condition evaluation at emission inspection, resulting in an increased informative capability of emission inspection;

- the increasing of efficiency of emission inspection performance;

- the prevention of human factor's negative effect at emission inspection and at its evaluation.

The innovative method of engine emission inspection must be in accordance with legislative requirements and must:

- consider the variety of construction solutions for spark ignition systems, systems of fuel mixtures formation, as well as their control;

- be universal and applicable to a wide spectrum of used construction solutions for motor vehicles engines;

- provide a universal, fast, economically and technologically useful, and correct assessment of the emission condition of an engine and its accessories;

- enable using for a wide spectrum of used construction solutions for motor vehicles with petrol engines and an advanced emission system.

\section{Verification of a proposed methodology of emission inspection and its assessment}

Based on verification by means of experimental measurements and tests on a sample of motor vehicles, it was important to assess the proposed methodology in terms of its universality and practical use for motor vehicles with petrol engines and an advanced emission system.

\section{Used instruments and measuring devices}

All the measurements of volumes of emitted pollutants were performed with instruments and measuring devices accredited by the Ministry of Transport, Construction and Regional Development of the Slovak Republic for use in emission inspections of motor vehicles. All the used types of emission analysers must be in accordance with technical requirements for measuring devices, must work within accuracy class 0 , and must be in accordance with the OIML 99 regulation requirements. All the measuring devices were verified and calibrated in accordance with legislative requirements. Emission analysers were equipped with a NO/ $\mathrm{NO}_{2}$ sensor for $\mathrm{NO}_{x}$ production monitoring.

\section{Results and discussion}

Considering the environment, the share of emitted pollutants as well as of fuel consumption and $\mathrm{CO}_{2}$ is decreasing. This positive trend is resulting in a sharp increase of the share of electronic failures in engines and their accessories, with almost a triple increase of those failures among vehicle categories manufactured from 1995 to 2010. This event is not only alarming but a serious negative impact on a significant decrease of emission inspection informative capability is also the fact that the most of electronic failures and electronic deviations are undetectable by measuring with the described measurement method. This impact is most reflected in vehicles manufactured from 2000.

The aim of this experimental measurement was to compare the volume of the main emitted engine pollutants measured in 


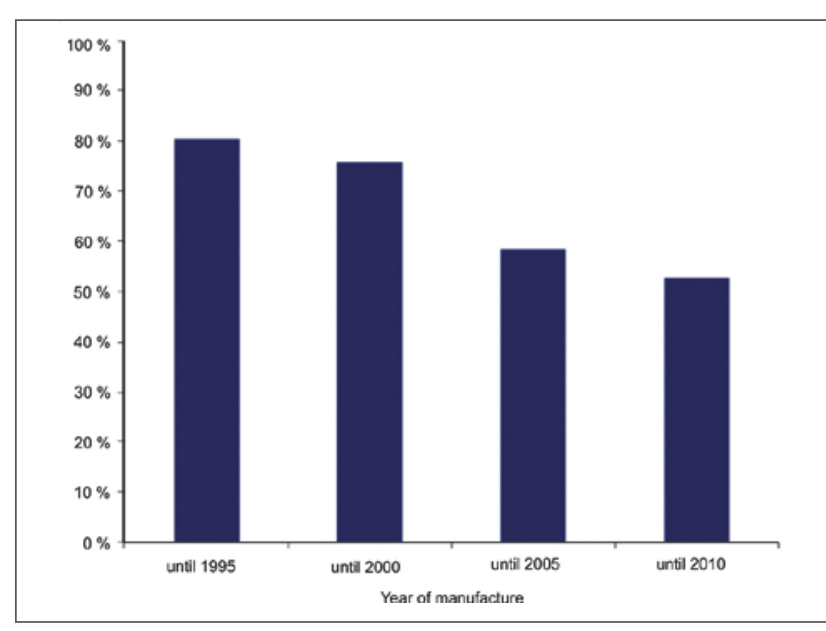

Figure 2 Informative capability of emission inspection in relation to the age of vehicles

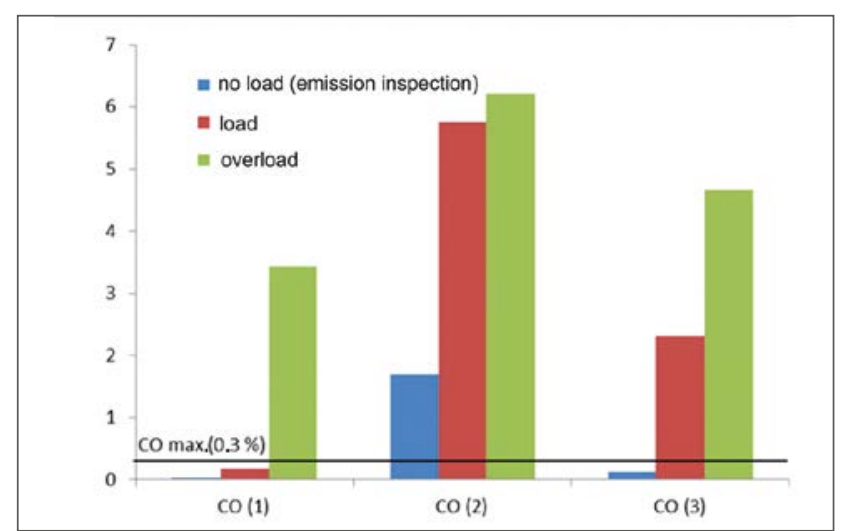

Figure 3 Informative capability of emission inspection in relation to the age of vehicles

emission inspections of an unloaded, loaded and overloaded engine. These comparisons were even performed at typical engine failure conditions. In comparisons, the values measured on an unloaded engine (such as in emission inspection) were considered as reference ones, identified by index 1 . The values identified by index 2 were measured at a failure simulation of the basic control system of mixture correction of $\lambda$ regulation. The values identified by index 3 were measured at a simulated failure of mixture calculation based on a defective pressure sensor in the intake pipe with a functional $\lambda$ regulation.

It is evident from comparing the $\mathrm{CO}, \mathrm{HC}$ and $\lambda$ values that emission values measured by the method used in vehicle emission inspections are comparable with those obtained with a loaded engine in a top condition. A significant deviation from reference values was recorded in an overloaded engine. It is obvious from comparing the $\mathrm{CO}$ and $\lambda$ values indicated at failures of the mixture correction system $\lambda$ that such failures are shown in unloaded engine measurement and are sufficiently detectable by emission inspection.

\section{Concept of method optimisation for emission inspection performance}

The proposed innovative method of emission inspection in motor vehicles significantly increases the informative capability of emission inspection $\eta_{E K}$ Besides a traditional emission measurement, this inspection method takes into account

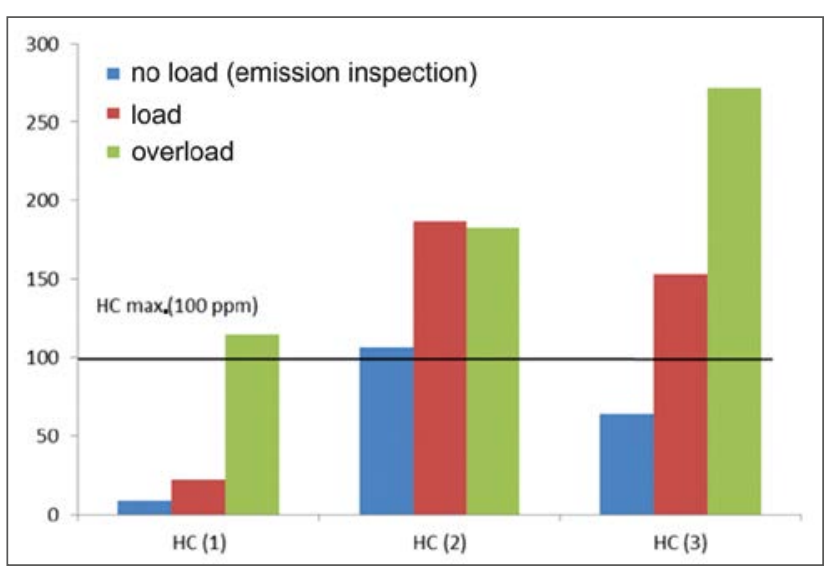

Figure 4 Informative capability of emission inspection in relation to the age of vehicles

an electronic inspection of engine regulation by means of monitoring the functions of on-board diagnostics (OBD), and implements into inspection an instant condition of the engine and its accessories as well as engine behaviour in various conditions during productive running. Such an inspection is thorough, but hardly implementable in practice in terms of:

- time demandingness;

- technological complexity;

- knowledge level of technicians.

Based on these reasons, it is important to optimise the proposed method of emission inspection in motor vehicles and to create a compromised solution that would ensure a sufficient informative capability $\eta_{E K^{\prime}}$ would not require a higher time demandingness, would not mean a complicated modification of technological equipment at workplace, an inadequate economic demandingness of workplace, and could be solvable with an actual knowledge level of technicians. An optimised method of emission inspection in motor vehicles was necessary to be verified by means of experimental measurements in terms of ensuring the efficiency of work in emission inspection at workplaces and in terms of ensuring a sufficient informative capability of emission inspection $\eta_{E K}$

In order to optimise the performance method, it was necessary to reassess various proposed actions of emission inspection. To reduce the time demandingness and the risk of limited communication from the measuring device, we propose to omit the following actions from emission inspection:

- inspecting the electronic course of a throttle valve;

- inspecting the availability of the main values for mixture calculation;

- inspecting the signal course of each monitoring $\lambda$ exhaust gas oxygen sensor;

- obtaining the number of errors recorded in the memory of transient errors together with error messages.

We propose to modify the scope of actions as follows:

- the action 'inspecting the signal course of each monitored $\lambda$ exhaust gas oxygen sensor' will be performed only if some of the monitored systems will be evaluated as 'not inspected' or 'failed' in the readiness code;

- the action 'obtaining the number of errors recorded in the memory of permanent errors together with error messages' will be assessed at failures of an engine and its accessories with the code POXXX, which failures are defined according to ISO 15031-6 and SAE 2012, where the 
vehicle will be evaluated as insufficient, and at failures of an engine and its accessories with the code P1XXX, which failures are not defined, only recommended according to ISO 15031-6 and SAE 2012, without any effect on vehicle evaluation, but with recommendation for inspection in a professional service. Other failures of an engine and its accessories with a code identified as $\mathrm{P}$ and $\mathrm{U}$ will not be displayed, or they will not be evaluated.

For emission measurement in a free-running engine regime, the stabilisation of parameters will be eliminated, and gaseous harmful emissions will not be evaluated in this regime. This measurement will be replaced by electronic inspection by means of OBD. For the free-running regime, it is important to evaluate the idle engine speed only.

\section{Concept of an innovative method for emission inspection performance}

The innovative method of emission inspection in motor vehicles optimised for emission inspection requirements, considering the time demandingness of emission inspection, technological complexity as well as knowledge requirements on emission inspection technicians, was prepared into several points of emission inspection methodology. This methodology describes the sequence of actions and their scope for the emission inspection of motor vehicles. Modifications of requirements for the technological equipment of an emission inspection station were also prepared, reflecting an optimised method of the emission inspection of motor vehicles incorporated in the methodical procedure.

The results demonstrate a significant effect of the electronic inspection of a vehicle by means of OBD on the informative capability of emission inspection. It is important to implement these results into practice and include them into regular emission inspections of vehicles with petrol engines put in operation after 1 January 2001. The following recommendations are important for implementation into practice:

- to include the electronic inspection by means of OBD into emission inspection within the scope of the proposed methodical procedure;

- to keep the traditional emission measurement according to the original methodical procedure as a basis of emission inspection;

- to prevent the opportunity for electronic inspection evading by an obligation to scan the values of engine revolutions and coolant temperature, exclusively by means of OBD;

- to implement modifications in the technological equipment of an emission inspection station for implementation needs of electronic inspection by means of OBD;

- to optimise the scope of training for implementing such a type of emission inspection;

- as the informative capability of emission inspection depends on the scope of inspected actions in electronic inspection, it will be important to consider the scope of inspected parameters in the future;

- to determine the informative capability of emission inspection in motor vehicles with petrol engines and the possibility of electronic inspection for those vehicles, and based on their evaluation, to seek opportunities for methodology innovation for the emission inspection of motor vehicles with petrol engines and their implementation into practice.

\section{Conclusion}

The development of motorvehicleshas resulted in a decrease in the informative value of emission inspection to such an extent that we would be able to capture by emission inspection only half the number of vehicles with the technical condition of the engine and its accessories showing failures or wear, meaning that the vehicle could be identified as damaged considering the engine. For that reason, it was important to innovate the original methodical procedure of emission inspection so that the informative capability of emission inspection increases to ensure the demonstrativeness of assessment in relation to the factual condition of the engine and its accessories. The submitted method of emission inspection of motor vehicles incorporated into the methodical procedure complies with such requirements.

In cooperation with the Ministry of Transport, Construction and Regional Development of the Slovak Republic, the technical service of emission inspection of motor vehicles S-EKA, spol. s r. o. (private limited company) at Nitra is accredited to elaborate requirements for practice focused on the detection of emission condition of motor vehicles with a petrol engine and an advanced emission system.

\section{Acknowledgement}

This paper was prepared with the support of the Ministry of Education of the Slovak Republic, project VEGA 1/0857/12 'Reducing of unfavourable impacts of agricultural and transport machinery on the environment'.

\section{References}

BIBZA, S. 2007. Pozícia automobilového priemyslu. In: MOTOR, Nová technika, č. 1, 2008. ISSN 1336-4200.

LENĎÁK, P. 2008. Ekologická bezpečnost' motorových vozidiel v prevádzke. In International Scientific Conference New Trends in the Construction and Exploitation of Vehicles 'VEHICLES 2007'. Nitra. LENĎÁK, P. 2012. Hodnotenie metód vykonávania emisnej kontroly pre vozidlá so zážihovým motorom a zdokonaleným emisným systémom : doktorandská dizertačná práca. Nitra : SPU, 2012, $188 \mathrm{~s}$.

ŠIMOR, R. - JANOŠKO, I. 2008. Problematika emisií spal'ovacieho motora. In 34. ročník mezinárodní konference kateder dopravních, manipulačních, stavebních a zemědělských strojů. Ostrava : Technická univerzita báňská, roč. 9, 2008, s. 1-12. ISBN 978-80-248-1820-7.

VYHLÁŠKA MDPT SR č. 578/2006 Z. z., ktorou sa ustanovujú podrobnosti o niektorých ustanoveniach zákona č. 725/2004 Z. z. o podmienkach prevádzky vozidiel $v$ premávke na pozemných komunikáciách a o zmene a doplnení niektorých zákonov v znení neskorších predpisov.

ZÁKON č. 142/2000 Z. z. o metrológii a o zmene a doplnení niektorých zákonov.

ZÁKON č. 725/2004 Z. z. o podmienkach prevádzky vozidiel v premávke na pozemných komunikáciách a o zmene a doplnení niektorých zákonov.

Contact address:

Ing. Peter Lendák, PhD., S-EKA, spol. s r. o., Kupecká 5, 94901 Nitra, Slovakia, e-mail: lendak@seka.sk; Ing. L'ubomír Hujo, PhD., Ing. Juraj Jablonický, PhD., Ing. Michal Angelovič, Department of Transport and Handling, Faculty of Engineering, Slovak University of Agriculture in Nitra, Tr. Andreja Hlinku 2, 94976 Nitra, Slovakia, e-mail: lubomir. hujo@gmail.com 